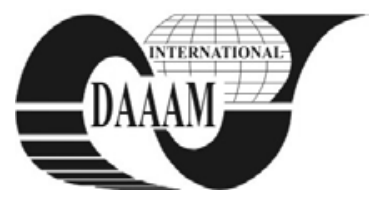

Annals of DAAAM for 2011 \& Proceedings of the 22nd International DAAAM Symposium, Volume 22, No. 1, ISSN 1726-9679 ISBN 978-3-901509-83-4, Editor B. Katalinic, Published by DAAAM International, Vienna, Austria, EU, 2011 Make Harmony between Technology and Nature, and Your Mind will Fly Free as a Bird Annals \& Proceedings of DAAAM International 2011

\title{
THE ROLE OF SELF-SERVICE TECHNOLOGIES IN CROATIAN GROCERY RETAILING
}

\author{
VOUK, R[udolf]; GUSZAK, I[rena] \& SISEK, B[oris]
}

\begin{abstract}
The paper explores presence of self-service technologies in Croatian grocery retailing and specific benefits self-service technologies create on Croatian grocery market. Croatian grocery retailers use two forms of self-service technologies: self-checkouts and self-scanning systems. Research identified several specific benefits of self-service technologies implementation in Croatian grocery retailing.
\end{abstract}

Key words: self-service technologies, retail, grocery, Croatia

\section{INTRODUCTION}

Intense competition in the groceries market forces grocery retailers to continuously seek new competitive advantages. One of potential sources of competitive advantages are technology innovations. Examples of such technologies are self-service technologies. Self-service technologies are defined as technological interfaces that enable customers to obtain a service without direct assistance from service employees (Schliewe \& Pezoldt, 2010). Retailers use two forms of selfservice technologies in their stores: stationary self-checkouts and portable self-scanning systems. The main motive for implementation is providing customers with greater choice and convenience (ECR Europe, 2011).

The main purpose of this paper is to overview self-service technologies employed in grocery retailing, establish presence of self-service technologies in Croatian grocery retailing and identify specific benefits self-service technologies create on Croatian grocery market. Data presented in the paper were gathered through an extensive literature overview and interviews with managers of Croatian grocery retailers who use self-service technologies.

\section{SELF-SERVICE TECHNOLOGIES RETAILING}

Every distribution channel encompasses a set of functions that need to be completed in order to ensure that desired products and services will reach their consumers. Some of the functions are information gathering, financing, storage and movement of physical products, ownership transfers. Each of these functions generates costs associated with it. In order to avoid or minimize such costs, every channel member is looking to transfer more functions and costs to other channel members. Often, channel tasks and costs are transferred to the last channel member, the consumer, and companies are getting customers to perform more tasks of the shopping process themselves.

Lifestyle trends created customer segments whose most scarce resource is time. Such customers are willing to employ more energy and effort in the shopping process, if that would save time they spent shopping. Studies showed that 10 per cent of shoppers who leave a store without making a purchase named 'checkout waiting time' as a key factor in their decision (Müller, 2008). Self-service technologies enable customers to obtain a service independently of service staff, namely, they do not have to wait in lines in front of counters and cashiers.
Omnipresent types of tasks supported by self-service technologies transferred to customers are many. For instance, petrol stations introduced self-service pumps with charging systems which customers use to pay themselves, banks launched ATMs (ECR Europe, 2011), on-line and mobile phone banking, companies operating highways integrated noncash methods of toll payment, such as ENC systems, or use of credit and debit cards. Then, public parking and tram/bus fares are payable by mobile phones, check-in at airports can be done on-line or at check-in kiosks. Book returns to libraries, hotel check-out systems and movie ticket kiosks are also forms of self-service technologies widely used (Kinard et al., 2009).

Self-services based on technology innovations also entered the retail sector. Examples of out of store self-service technologies are on-line shopping, using both a personal computer and a mobile phone. In store self-service technologies are present in forms of stationary self-checkouts and portable self-scanning systems. Self-checkout is a fixed device where customers bring their goods, scan them and arrange payment themselves, first introduced in 1992 in US (ECR Europe, 2011). Self-scanning systems are based on a hand held device which customers use to scan goods as they choose them around the store. When they are ready to pay, customers take scanners to payment points where staff members arrange for payment, or customers can use self-paying kiosks and arrange for payment themselves (ECR Europe, 2011). Early technology adopters were large volume retailers, such as supermarkets, hypermarkets and DIY type retailers (ECR Europe, 2011).

The main reason retailers use self-service technologies is providing the customer with greater choice, service and convenience (ECR Europe, 2011). Usually, four to six selfcheckouts are supervised by one employee. That reduces need for labour and results in cost savings. Self-service technologies allow redeployment of store staff, hours formerly spent at the front cashiering are now translated into hours spent on other tasks, such as customer service (SelfService World, 2009).

Additional positive effects for retailers are higher rates of card payments and less cash manipulation, and shorter time for checkout, so customers can spend more time between shelves (Datalogic, nd). The further potential of self-scanning systems are additional exclusive services that could be added: real time special offers, discounts while shopping, order-picking for internet orders, digital merchandising etc. (Datalogic, nd).

In order to improve the customer service, retailers allocate more labour to tasks like stocking inventory, answering questions in aisles, promoting specials etc. All that expands services offered and improves customers' shopping experience (SelfService World, 2009). Customers benefit from shorter customer lines and reduced checkout time, since stores are often able to efficiently run two to six self-checkout units instead of one traditional cashier (Schliewe \& Pezoldt, 2010). Implementation of self-service technologies transfers several tasks from the shopping process to customers and they gain control over them. Since customers can influence how shopping tasks are performed, they are more likely to have a good shopping experience (SelfService World, 2009). 
The biggest concern related to self-service technologies is security, namely, preventing products from leaving the store without payment (SelfService World, 2009). Other issues include the legal aspect on how to prevent minors and already intoxicated customers from buying alcohol (SelfServce World, 2009), as well as how to efficiently remove security tags.

It takes one to two years for self-service technology implementation projects to reach a positive ROI, so benefits overcome challenges. Productivity is derived from increased labour productivity, which is based on redistribution of tasks, and higher level of customer service (SelfService World, 2009).

\section{SELF-SERVICE TECHNOLOGIES CROATIAN GROCERIES RETAILERS}

In order to explore the role of self-service technologies on the Croatian grocery retailing market, authors interviewed managers from retailers that use self-service technologies. There were two such companies. They are both market leaders, operating various formats nationwide. The first company uses self-checkout and the other one self-scanning technology.

First self-checkouts were implemented in 2007 and today are available in five stores. It is interesting that besides in Zagreb, all stores with self-checkouts are located on the coastline. Self-checkouts can be very appealing to tourists, as they offer a selection of languages a customer can use to operate them. Also, tourists usually buy small and medium baskets, suitable for maximising benefits from self-checkouts.

Among others, benefits for customers are full control over processes of scanning and paying, and privacy in shopping. Then, customers have full control over data accuracy, checkout lines are shorter and shopping experience is enhanced by the opportunity to use the new technology. Self-checkouts are very interesting to children, as they can scan products themselves.

The retailer is happy with the customers' response to selfcheckouts. About 35 per cent of transactions in stores that offer self-checkouts are done using self-service technology. Key benefits for this retailer were shorter checkout lines, hence, shorter waiting for checkout and increased store traffic flow.

The second researched retailer introduced self-scanning system store in August 2010. Existing customers were segmented and the retailer approached potential early adopters. In result, 75 per cent of initially invited customers regularly use scanners when shopping for groceries in that store.

Motives for introducing self-service technologies in store were additional feature to the loyalty program and a means of reward for loyal customers. Also, the company was looking to shorten time necessary for shopping, especially time spent waiting in lines for checkout. Expected outcomes were better service for customers, higher labour productivity, process optimisation and lower shopping time. Benefits this innovation intended for customers were free additional service, simple to use, less time necessary for shopping and expenditure control.

Six months after the launch, the retailer is happy with the project results. Their integrated system achieved better efficiency and productivity, lower costs and improved customer service. Customers on average spend 50 minutes shopping in large formats and using a self-scan system can save them more than 15 minutes on average, mostly spent waiting in checkout lines. Analysis of shopping behaviour of loyal customers showed that value of their purchases increased 10 per cent when using self-scanners. It could be a result of better expenditure control, as customers can follow the total value of items scanned on the scanner and shop within their budget limits, or customers enjoy scanning, so they buy more products.

Challenges this retailer faced implementing self-scanners were difficulties with scanning bar codes that were unreadable, organizing removing of security tags from products, security and shrinkage. For all potential challenges, procedures of resolving them are in place. Whenever the system registers a misuse of the scanner, it launches a warning and if necessary, customer's purchase is rescanned before payment. Also, random rescanning is used and each customer's basket could be checked. Overall, implementation of self-scanning system was successful and further roll out is planned, as well as introduction of self-payment kiosks and self-checkouts.

From analysis conducted, key effects of self-service technology implementation in Croatia can be derived. For retailers, they are better efficiency, better labour productivity, lower cost, 10 per cent sales increase among self-scan users, increased store traffic flow, shorter waiting for checkout, additional service offered, simplified and enhanced shopping experience, especially for foreign customers (self-checkout). Benefits from self-service for customers are better shopping experience, less time needed for checkout, full control over scanning and payment operations, information on total value of chosen products - easier shopping within the budget (self-scan) and more privacy while shopping.

\section{CONCLUSION}

Analysis of self-service technology employment in retail showed several specifics of Croatian grocery market. They are significance of multilingual self-checkouts, primarily for stores located in tourist areas. The level of shrinkage is not higher than with the traditional cashiers, and customers using selfscanners spend 10 per cent more than they used to.

Self-service technologies in Croatian grocery market create a win-win situation for retailers and their customers. However, these results need to be observed in the context of research limitations. Main limitation of this research is a small sample of companies analysed, although they were the only one that fit the research criteria. This could be improved by repeating the research after more companies implement self-service technologies, or by expanding research to a broader geographic area. In addition, it would be interesting to focus further research on innovative solutions, such as using a mobile phone as a scanner and applicability of self-service technologies in small store formats. In conclusion, self-service technology manufacturers are constantly innovating their solutions, which retailers should use to offer their customers a better service and enrich their shopping experience.

\section{REFERENCES}

Datalogic (nd). Delhaize retains more and more customers with Datalogic "Self-Scanning" systems, Available from: http://www.datalogic.com/cgi-

bin/pdf/case\%20studies/eng/DELHAIZE-eng.pdf Accessed: 2011-02-08

ECR Europe (2011). The impact and control of shrinkage at self-scan checkouts, Available from: http://global.networldalliance.com/downloads/white_papers /NS_G_Self-Checkout_To\%20Launch.pdf Accessed: 201102-08

Kinard, B. R., Capella, M. L. \& Kinard, J. L. (2009). The Impact of Social Presence on Technology Based SelfService Use: The Role of Familiarity. Services Marketing Quarterly, Vol 30, pp. 303-314, ISSN: 1533-2977

Müller, A. (2008) Self-service shopping: Advantages for both retailers and customers. The Retail Digest, December 2008, pp. 50-53

Schliewe, J. \& Pezoldt, K. (2010). A Cross-Cultural Comparison Of Factors Influencing Self-Scan Checkout Use. Journal of Business \& Economics Research, Vol 8, No. 10, October 2010, pp. 39-47, ISSN: 1542-4448

SelfService World (2009). Self Checkout, Available from: http://global.networldalliance.com/downloads/white_papers /NS_G_Self-Checkout_To\%20Launch.pdf Accessed: 201102-08 